\title{
ANALISIS METODE KRITIK HADITS DAN PANDANGAN HUKUM INDONESIA TERHADAP BERITA HOAX
}

\author{
Derry Angling Kesuma \\ Sumpah Pemuda School of Law (STIHPADA) Palembang, Indonesia \\ Email: kesumaderry@gmail.com
}

\begin{abstract}
Abstrak
Pengguna internet di Indonesia sudah mencapai 196,7 juta pengguna. Era industri 4.0 ini memungkinkan pengguna untuk mengakses, mendapatkan dan menyebarkan berita dan informasi dimanapun dan kapanpun dengan lebih mudah, namun hal ini juga memudahkan untuk berbagai pihak menyebarkan berita hoax. Penelitian ini berjenis penelitian kualitatif dengan analisis yuridis-komparatif. Data yang diperoleh berupa data sekunder, yang diperoleh melalui kajian pustaka. Analisa didasarkan pada analisis liturgis dari berbagai sumber data yang dianggap valid, berdasarkan kondisi yang dialami masyarakat saat ini. Metodologi penelitian ini terdiri dari pendekatan deskriptif dan pendekatan kepustakaan. Dari hasil penelitian ini, dapat diketahui bahwa Metode kritik hadits bisa menjadi acuan bagi masyarakat untuk memverifikasi, apakah berita yang diterima apakah ada penambahan

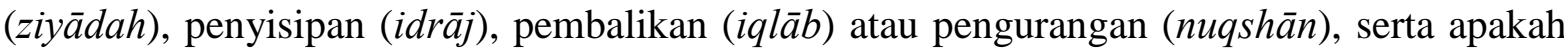
substansinya sesuai dengan kenyataan atau tidak. Sedangkan menurut hukum Indonesia, terdapat Pasal 45a yang mengatur tentang ancaman terhadap penyebar berita bohong dan pidana penjara paling lama enam tahun, dengan pidana denda paling banyak Rp. 1.000.000.000,- (Satu Miliar Rupiah) serta penyebar berita palsu dipastikan Melanggar Pasal 28 (1) Undang-Undang Nomor 11 Tahun 2008 yang mengatur tentang Informasi dan Transaksi Elektronik.
\end{abstract}

Kata Kunci: Hoax, Hukum Pidana Islam, Hukum Indonesia.

\begin{abstract}
Internet users in Indonesia have reached 196.7 million users. This industrial era 4.0 allows users to access, obtain and disseminate news and information more easily at any time, but this also makes it easier to spread hoax news. This research is a qualitative research with comparative-juridical analysis. The data obtained in the form of secondary data, obtained through a literature review. The analysis is based on liturgical analysis from various data sources that are considered valid, based on the conditions experienced by society today. The research methodology consists of a descriptive approach and a library approach. From the results of this study, it can be seen that the Hadith criticism method can be a reference for the community to verify whether the news received is whether there are additions (ziyādah), insertions (idrāj), reversals (iqläb), or subtractions (nuqshān), and whether the substance is appropriate with reality or not. Meanwhile, according to Indonesian law, there is Article $45 a$ which regulates threats to spreaders of fake news and a maximum imprisonment of six years, with a maximum fine of Rp. 1,000,000,000,- (One Billion Rupiah) and those who spread fake news are confirmed to have violated Article 28 (1) of Law Number 11 of 2008 which regulates Information and Electronic Transactions.
\end{abstract}

Keyword: Hoax, Islamic Criminal Law, Indonesian Law. 


\section{A. PENDAHULUAN}

Berita memiliki peran khusus dalam masyarakat demokratis: berita adalah sumber utama informasi akurat tentang urusan politik dan sosial, yang menginformasikan pembuatan opini publik dan proses deliberatif. Di sisi lain, segala fasilitas memberikan ruang yang sangat luas bagi penyebaran hoaks dan berita palsu di masyarakat sehingga menimbulkan keresahan masyarakat (Pranesti \& Arifin, 2019). Berita palsu adalah informasi yang sengaja dibuat dan disebarluaskan dengan maksud menipu dan menyesatkan orang lain untuk mempercayai kebohongan atau meragukan fakta yang dapat diverifikasi (Purnomo \& Joshua, 2021).

Informasi digital besar-besaran yang tersebar di media sosial online, hal ini merupakan salah satu ancaman utama bagi masyarakat kita (Rifaudddin \& Halida, 2018). Internet menyediakan sarana baru untuk menyebarkan berita palsu dalam skala luas dan cepat. Ketika internet tersedia untuk umum, memungkinkan bagi siapa saja untuk mengaksesnya. Pada saat yang sama, inovasi dalam komputer membuat mereka tidak terjangkau bagi kebanyakan orang. Membuat informasi tersedia di internet adalah cara baru untuk mempromosikan produk dan membuat informasi tersedia untuk hampir semua orang secara instan (Choiroh, 2017).

Pemerintah selalu menekankan bahwa masyarakat memiliki tanggung jawab untuk ambil bagian dalam memecahkan masalah ini. Namun, yang tak kalah penting adalah respons kuat dari masyarakat sipil yang secara tegas menentang kecenderungan penyebaran berita palsu. Penting untuk menjaga konsensus masyarakat secara keseluruhan dan untuk meningkatkan kesadaran kolektif. Komunikasi elektronik telah menjadi bagian penting dari kebudayaan modern dan telah mengubah perilaku manusia dengan sangat kontras pada saat yang sama sehingga mengubah cara pandang terhadap suatu berita atau informasi yang beredar, hal ini perlu menjadi perhatian serius bagi pemerintah.

Sosial Media bukan hanya mengubah cara penyampaian sebuah informasi, namun mengubah juga sudut pandang orang yang menerimanya (Afandi, 2018). Perkembangan yang sangat besar tersebut juga berdampak pada perkembangan interaksi hukum dan interaksi sosial. Selain memberikan dampak positif berupa kemudahan berinteraksi yang tidak terbatas ruang dan waktu, media teknologi informasi juga memberikan dampak negatif bagi penggunanya (Arifin, 2018). Permasalahan yang sering terjadi adalah tidak adanya pengendalian dan cenderung disalahgunakan untuk tindakan kejahatan seperti human trafficking, penyebaran berita hoax, provokasi, fitnah, hacking, pembobolan data khususnya perbankan, dan kejahatan cyber lainnya (Azhar, 2017).

Salah satu dampak terbesar dari perkembangan media sosial adalah gencarnya penyebaran berita hoax (Chumairoh, 2020). Karena transmisi berita melalui media berbasis online saat ini tidak terbatas pada situs berita saja, tetapi semua orang sebagai pengguna internet dapat ikut serta dalam penyebaran informasi tersebut (Hidayat, Eddy \& Sahari, 2020). Sayangnya, sebagian besar informasi dan berita yang tersebar secara individu atau suatu kelompok jauh lebih tidak bertanggung jawab dalam hal ketepatan sumber berita dan validasinya. Informasi tersebut diberikan sebagai berita atau dapat ditafsirkan demikian (Irpan, 2020). Tidak seperti banyak jenis informasi lainnya, berita memainkan peran khusus dalam masyarakat demokratis: berita adalah sumber utama informasi akurat tentang urusan 
politik dan kemasyarakatan, yang menginformasikan pembuatan opini publik dan proses musyawarah (Junaidi, Eddy \& Sahari, 2020).

Di Indonesia, maraknya hoax telah meningkat menjadi krisis nasional, menyebabkan konflik, ketidakstabilan politik, dan gangguan keamanan (Mujib, 2017). Banyaknya kasus hoaks yang terjadi di Indonesia memicu gelombang demonstrasi dan permusuhan antar kelompok, yang mengakibatkan ketidakstabilan nasional, terutama menjelang tahun politik. Misalnya, situs resmi Kominfo pada akhir Juni 2021 memberikan daftar berita hoax yang sudah terlanjur tersebar di berbagai sosial media dan telah menciptakan kepanikan di tengah masyarakat, diantaranya: 1) "6 Times more people died from the Covid-19 vaccine the virus in Scotland"; 2) "Pemerintah pinjam Rp. 13 Triliun dari Bank Dunia untuk Lockdown"; dan 3) "Undangan Rapat Koordinasi Calon Penerima dan Penandatanganan Perjanjian Program Bantuan Dana Hibah TA. 2021"

Para pelaku penyebar hoax semakin terbantu dengan minimnya pemfilteran berita di media sosial, sehingga memudahkan penyebaran berita apapun dalam postingan seseorang (Novitawati, Parman \& Sabardi, 2019). Hal ini sejalan dengan survei wabah hoaks nasional Masyarakat Telematika Indonesia yang diketuai oleh Sarwoto Atmosuratno (Periode 20212024) menyatakan bahwa saluran distribusi berita hoaks yang paling umum digunakan di Indonesia adalah melalui media sosial (92,40\%) diikuti oleh Aplikasi Chat $(63,80 \%)$, Website (35,90\%), TV (8,89\%), Media Cetak (6\%), Email (3,20\%) dan Radio (1,30\%). Jenis hoaks yang paling banyak diterima masyarakat Indonesia adalah terkait sosial politik $(92,80 \%)$ dan isu SARA $(87,60 \%)$.

Upaya yang diprioritaskan bersifat preemtif dan preventif tetapi penegakan akan dilakukan jika tidak efektif (Setiawan, 2018). Telegram Polri dibentuk untuk mencegah penyebaran, melalui Peraturan Presiden 11 Tahun 2020 Covid-19, Peraturan Pemerintah Nomor 21 Tahun 2020 tentang SOS dan Undang-Undang Stabilitas Sistem Keuangan Negara (Peraturan Pemerintah Nomor 21 Tahun 2020) melalui Telegram Polri untuk mencegah penyebaran berita Covid-19 ini. Kendala itu ada, baik secara yuridis dengan kaidah, teori, fiqh maupun batas-batas etika sosial (Toni, 2020).

Metode kritik hadis dapat didefinisikan sebagai cabang ilmu hadis yang digunakan untuk memverifikasi hadis untuk membedakan antara yang shahih dan tidak. Proses otentifikasi hadits harus dilakukan karena transmisi hadits, yang melalui satu generasi orang. untuk yang lainnya. Orang-orang secara karakteristik berbeda; ada yang memiliki integritas dan kepribadian yang baik, ada pula yang amoral dan kurang cerdas. Selain itu, juga merupakan akibat dari pemalsuan hadits yang terjadi dalam sejarah kodifikasi hadits itu sendiri. Dengan kata lain, metode kritik hadis muncul karena adanya informasi yang perlu diverifikasi. Metode kritik hadits mencakup dua aspek, yaitu: (1) Sanad (rantai perawi) dan Matan (isi hadits). Cendekiawan Muslim telah mengkonstruksi prinsip-prinsip dalam membuat kritik hadits, baik sanad maupun matan. Beberapa di antaranya relevan untuk dikontekstualisasikan dalam memverifikasi penyebaran informasi di media sosial. Pada bagian berikut, akan dikemukakan bahwa beberapa prinsip dalam metode kritik hadis dapat digunakan untuk memerangi hoax, hal ini penting diuraikan bagaimana mengkontekstualisasikannya dalam hal media sosial.

Kajian pemberitaan hoax menjadi penting karena lemahnya penegakan hukum. Hal ini dikarenakan berbagai elemen yang mempengaruhi proses penegakan hukum terkait berita 
hoax. Dalam hal ini, substansi hukumnya jelas: laporan hoax melanggar Pasal 28 ayat 1 Undang-Undang Nomor 11 Tahun 2008 tentang Informasi dan Transaksi Elektronik (Maskum, 2017). Secara teknis, dari sisi aparat penegak hukum dinilai kurang berhasil dalam mengadili pelaku karena tidak memiliki efek jera (Siddiq, 2017).

\section{B. METODE}

Penelitian ini berjenis penelitian kualitatif dengan analisis yuridis-komparatif. Data yang diperoleh berupa data sekunder, yang diperoleh melalui kajian pustaka. Analisa didasarkan pada analisis liturgis dari berbagai sumber data yang dianggap valid, berdasarkan kondisi yang dialami masyarakat saat ini. Metodologi penelitian ini terdiri dari pendekatan deskriptif dan pendekatan kepustakaan. Penelitian ini bertujuan untuk menganalisis dan membandingkan perspektif hukum pidana Islam dan perundang-undangan Indonesia tentang pemberitaan hoax. Penelitian ini mengumpulkan data dari buku, jurnal, dan sumber lain yang terkait atau relevan dengan tujuan penelitian. Metode deskriptif digunakan untuk mendapatkan informasi spesifik tentang metode kritik hadits dan hukum Indonesia untuk menangkal penyebaran berita hoax.

\section{HASIL DAN PEMBAHASAN}

Berita palsu dapat dibagi menjadi beberapa jenis, sebagai berikut: 1) Fabrikasi. Cerita fiksi yang terputus dari fakta nyata; 2) Propaganda. Contoh khusus cerita rekayasa yang bertujuan merusak kepentingan pemerintah dalam konteks politik; 3) Teori konspirasi. Merujuk pada cerita yang mencoba menjelaskan situasi atau peristiwa dengan melakukan konspirasi tanpa bukti; 4) Hoaks. Berita yang mengandung fakta palsu atau tidak akurat dan disajikan sebagai fakta yang sah. Kategori ini juga dikenal sebagai cerita setengah kebenaran atau fakta; 5) Berita sepihak. Jenis ini dikenal sebagai berita hiper-partisan dan sangat bias; 5) Rumor. Mengacu pada cerita yang ambigu atau tidak pernah dikonfirmasi; dan 6) Clickbait. Mengacu pada penggunaan yang disengaja dari tajuk utama dan konten thumbnail yang menyesatkan di Web. Pemerintah telah mengidentifikasi beberapa pihak yang dapat menyebarkan berita palsu, termasuk 1) Bot; 2) Organisasi Kriminal/Teroris; 3) Aktivis atau Organisasi Politik; 4) Jurnalis; dan 5) Penyebar Teori Konspirasi (Pakpahan, 2017).

Ada beberapa faktor yang menyebabkan munculnya berita palsu di Indonesia, antara lain: 1) Kemudahan memiliki alat komunikasi yang modern dan murah; 2) Kemudahan untuk menerima dan terpengaruh oleh informasi yang tidak jelas tanpa memverifikasi atau mengkonfirmasi keabsahan informasi; dan 3) Minimnya minat baca masyarakat sehingga dalam menganalisis suatu berita tidak berdasarkan data akurat, hanya mengandalkan daya ingat atau sumber yang tidak jelas. Berita palsu yang beredar di media sosial juga biasanya berupa ancaman, termasuk setiap perbuatan melawan hukum yang berupa ucapan, tulisan, gambar, lambang, atau gerak tubuh, baik dengan maupun tanpa menggunakan sarana dalam bentuk elektronik atau nonelektronik yang dapat menimbulkan ketakutan terhadap orang atau masyarakat pada umumnya atau menahan kebebasan komunitas tertentu. Tindak pidana ini pada dasarnya bersifat transnasional dan terorganisir karena bersifat gerakan rahasia, terselubung, atau bawah tanah, lintas negara yang didukung oleh pemanfaatan teknologi modern di bidang komunikasi, informatika, transportasi dan persenjataan modern sehingga memerlukan kerjasama ditingkat internasional. 
Oleh karena itu, dengan menganalisis definisi dan penjelasan dalam Hukum Indonesia, dapat disimpulkan bahwa penggunaan undang-undang antiteror untuk menjerat pelaku penyebaran berita bohong tidak relevan dan berlebihan, karena di Indonesia diterapkan asas kepastian hukum. Asas kepastian hukum lebih banyak diterapkan di lembaga peradilan dimana hakim mengutamakan peraturan perundang-undangan pada hasil proses legislasi. Dalam perkembangannya, kedudukan pengadilan dan hakim dalam sistem hukum perdata memiliki beberapa ciri, yaitu: (1) kedudukan dan fungsi hakim terbatas, hakim hanya berfungsi menerapkan undang-undang dan tidak boleh membuat undang-undang baru; (2) kedudukan hakim sebagai bagian dari yudikatif sejajar dengan legislatif dan eksekutif. Jadi, cabang-cabang otorisasi harus saling menghormati. Hakim tidak dapat membatalkan putusan atau produk hukum dari cabang lain; (3) hakim hanya sebagai teknisi hukum sehingga yang dapat dilakukannya hanyalah menganalisis fakta-fakta dalam kasus yang ditangani kemudian mencari hukum yang mengikuti fakta tersebut; dan (4) hakim dalam sistem hukum perdata hanyalah salah satu mata rantai dalam birokrasi pemerintah yang menjalankan tugas-tugas rutin (Marwan \& Ahyad, 2016).

Berdasarkan ciri-ciri di atas, terlihat bahwa putusan yang dihasilkan oleh hakim Indonesia hanya bersifat yuridis-redaksional. Hakim lebih berpikir dalam lingkup pemecahan masalah yang diambil dari paparan hukum yang sistemik dan berwibawa dan mencari penyelesaian dengan menggunakan klausa dan prinsip umum. Bahkan dalam kasus hoaks, hakim lebih banyak menerapkan apa yang diatur dalam UU ITE daripada menggali kebenaran substantif kasus tersebut. Banyak kasus hoax yang beredar dengan menggunakan Pasal 28 Ayat ke-(1) dan (2) UU ITE, menurut Pasal 28 Ayat ke-(1) UU ITE, setiap warga negara yang menyebarkan berita bohong dan menyesatkan masyarakat dengan sengaja dan tanpa hak menyebabkan kerugian dalam Transaksi Elektronik akan dikenai hukuman. Mengenai penyebutan kata "menyebarkan berita bohong" dalam Pasal 28 ayat (1) UU ITE, terdapat ketentuan serupa dalam Pasal 390 KUHP. Namun, dengan kalimat yang sedikit berbeda, yaitu dengan frasa "menyiarkan berita palsu". Menurut Pasal 390 KUHP: "Barang siapa dengan maksud menguntungkan diri sendiri atau orang lain dengan menentang hak untuk menurunkan atau menaikkan harga barang dagangan, dana atau uang surat berharga dengan menyiarkan berita bohong, dipidana dengan pidana penjara selama dua tahun delapan bulan". Diantaranya, Pasal 28 ayat (2) UU ITE menyatakan bahwa "Setiap orang dengan sengaja dan tanpa hak menyebarkan informasi yang bertujuan menimbulkan kebencian atau permusuhan individu dan/atau kelompok tertentu berdasarkan suku, agama, ras, dan antargolongan (SARA)". SARA adalah topik yang sangat sensitif di dalam masyarakat. Akibatnya, pasal ini diatur oleh pelanggaran formal daripada pelanggaran materi. Salah satu contohnya adalah postingan status jejaring sosial yang berisi hinaan yang ditujukan kepada kelompok etnis/agama tertentu untuk memprofokasi individu untuk membenci atau melakukan tindakan anarki terhadap kelompok tertentu.

\section{Kontekstualisasi Metode Kritik Hadis untuk Menahan Perkembangan Hoax}

Otentisitas hadis telah menjadi perhatian para sarjana Islam klasik sejak masa awal Islam. Untuk itu, mereka membuat tolak ukur untuk menganalisis mana hadits yang shahih dan mana yang tidak. Tolok ukur atau kriteria tersebut meliputi kriteria eksternal (al-khārij) dan internal (al-dakhilkh). Ibnu Shalah mengatakan bahwa hadits shahih adalah "hadits yang 
memiliki isnad yang berkesinambungan, terdiri dari pelapor yang dapat dipercaya dari otoritas serupa, dan yang ditemukan bebas dari penyimpangan (yaitu dalam teks) atau cacat (yaitu dalam isnad)". Definisi yang dijelaskan oleh Ibnu Shalah ini merupakan definisi yang banyak dipilih oleh para ulama. Namun, definisi tersebut bukan tanpa kritik. Kritik tidak hanya datang dari para sarjana Barat tetapi juga para sarjana Muslim kontemporer.

Kriteria yang dipertimbangkan meskipun mencakup dua kriteria, tetapi hanya menekankan kriteria eksternal, dan cenderung mengabaikan kriteria internal. Hal ini sebenarnya bisa dimaklumi karena memang ulama klasik ketika menguji validitas internal hadis lebih menekankan pada format matan; apakah ada penambahan (ziyādah), penyisipan (idrāj), pembalikan (iqlāb) atau pengurangan (nuqshān) yang dapat mengakibatkan kontradiksi dalam hadits atau antar hadits itu sendiri, yang pada gilirannya akan berdampak pada hadits menjadi lemah. Cendekiawan Islam klasik kurang memperhatikan substansi hadits, yang sebenarnya tidak kalah pentingnya untuk pengujian. Melihat kritik-kritik tersebut, para ulama Islam kontemporer tidak tinggal diam dan kemudian mencoba merumuskan metode (manhaj) untuk mengkaji aspek internal, terutama dari segi substansinya.

Pengujian internal terhadap perkembangan hadits ini biasa disebut dengan kritik matan hadits. Al-Adlabi dalam karyanya menjelaskan bahwa substansi hadis tidak boleh bertentangan dengan (a) Al-Qur'an, (b) Hadits yang telah terbukti shahih, (c) Akal, dan (d) Sejarah. Pada saat yang sama, ad-Dumain̄̄ membedakan antara kriteria yang dimiliki oleh ahli hadis dan fuqaha. Menurutnya, di kalangan ahli hadis, sebuah hadits akan lemah (dha'if) karena mengandung unsur inkoherensi, yaitu bertentangan dengan (a) Al-Qur'an, (b) Hadits atau sunnah yang telah dibuktikan kebenarannya. otentik, (c) Hadits atau sunnah yang telah ditetapkan, (d) Bahasa Arab yang benar, (f) Fakta sejarah, prinsip dan aturan syariah yang tetap, dan (g) Akal sehat.

Sedangkan menurut ahli hukum, hadits matan diterima jika koheren, dan sebaliknya ditolak jika bertentangan dengan (a) Al-Qur'an, (b) hadits yang telah terbukti shahih, (c) ijma, ( d) praktik shahabah, (e) qiyas, (f) prinsip umum syariah, dan (g) prevalensi dalam kasus umum. Merujuk pada kritik terhadap hadits matan di atas, Syamsul Anwar kemudian mengklasifikasikannya menjadi dua preferensi, yaitu kriteria formal otentisitas matan dan kriteria substansial otentisitas matan. Menurut Syamsul Anwar, kriteria yang termasuk dalam kriteria formal otentisitas Matan adalah dua kriteria validitas hadis yang telah dibuat oleh para ulama, yaitu bebas dari syāż (anomali) dan 'illah. Yang dimaksud dengan "bebas dari syā $\dot{z}$ " adalah memiliki tiga unsur; (a) bebas dari pertentangan, (b) bebas dari pencemaran, dan (c) bebas dari kesalahan. Sedangkan yang dimaksud dengan "bebas dari 'illah" adalah mencakup beberapa unsur; (a) bebas dari kontradiksi internal dan (b) bebas dari interpenetrasi sosial (pencampuran satu matan dengan matan lainnya). Oleh karena itu, secara keseluruhan, unsur-unsur kriteria formal kritik Matan ada lima: tiga bebas dari shā $\dot{z}$, dan dua lagi adalah unsur yang bebas dari 'illah.

Kriteria substansial otentisitas matan yang dimaksud Syamsul Anwar dalam hal ini adalah terbebasnya sebuah hadits matan dari inkoherensi. Yang dimaksud dengan "bebas dari inkoherensi" adalah muncul keselarasan makna di antara hadis. Substansi maknanya bebas dari inkoherensi dengan beberapa makna yang telah diterima dan diakui. Bebas dari inkoherensi juga sebenarnya termasuk dalam salah satu unsur bebas 'illah. Kriteria ini lebih 
banyak berkaitan dengan substansi dan makna yang merupakan isi hadits daripada berkaitan dengan format matan. Misalkan kriteria informal, dan hadits lebih dilihat dari segi format matan, seperti apakah matan hadits dibalik urutannya atau tidak.

Salah satu prinsip kritik sanad yang relevan adalah mengetahui secara pasti perawi. Artinya perawi informasi bukanlah orang yang tidak dikenal (majhul), baik identitasnya, kepribadiannya maupun kredibilitasnya. Sementara jika sanad hadits berisi orang yang tidak dikenal, itu akan dianggap sebagai hadits yang lemah. Prinsip ini dapat diterapkan saat mendapatkan informasi melalui media sosial. Dalam hal media sosial, yang dapat dianggap sebagai narator adalah situs media. Sementara informasi yang dibawa oleh "situs media tidak dikenal", kita tidak bisa langsung percaya tanpa mencari identitas dan kredibilitas media yang dikutip. Dalam ilmu hadits, pencarian identitas dan kredibilitas perawi dapat dilakukan dengan merujuk pada kitab-kitab para Rawi (kitab Rijāl dan Tārīkh al-Ruwāh). Buku-buku ini diyakini oleh umat Islam sebagai sumber yang paling otoritatif untuk mencari identitas dan kredibilitas perawi hadits.

Pertanyaannya, kemudian, adalah bagaimana mencari "kredibilitas" situs media? Untuk itu, kita bisa merujuk pada data otoritatif tentang daftar situs media yang dimiliki Dewan Pers Indonesia (DPI) atau Kominfo. Cara verifikasi ini mungkin efektif untuk memerangi hoax karena sumbernya adalah media palsu dan situs media tidak dikenal yang belum diverifikasi baik secara faktual maupun administratif. Jika nama situs tidak muncul dalam pencarian, berarti situs tersebut belum diverifikasi. Kominfo telah memberikan peringatan bagi masyarakat luas untuk berhati-hati terhadap penyebaran berita palsu ini, terutama mengenai pemberitaan pandemi. Kominfo memeberikan langkah-langkah preventif untuk menghindari hal tersebut, diantaranya: 1) Hati-hati dengan judul yang bersifat provokatif. Biasanya berita seperti ini menampilkan judul yang sensasional, yang langsung menunjuk kepada suatu pihak sehingga menimbilkan persepsi yang negatif. Hal ini harus diimbangi dengan mencari referensi pada situs online yang resmi; 2) Mencermati alamat situs. Apabila situs tersebut belum terverifikasi sebagai institusi resmi, misalnya situ yang menggunakan domain blog, perlu diragukan kredibilitasnya. Menurut catatan DPI terdapat sekitar 43.000 situs yang mengklaim sebagai portal berita, namun yang terverifikasi tidak sampai 300-an situs; 3) Memeriksa fakta. Masyarakat hendaknya memperhatikan dari mana sumber dan siapakah yang menyebarkan berita tersebut. Selain itu, berita yang diterima haruslah berimbang, dalam arti sumbernya bukanlah sumber berita tunggal. Hal penting yang harus diamati oleh masyarakat adalah mengetahui perbedaan berita yang dibuat berdasar pada opini atau fakta; 4) Mengecek keaslian foto berita. Di era informasi saat ini, banyakl foto dan video yang bisa dimanipulasi. Mengecek keaslian foto di Google, bisa dengan teknik drag-and-drop ke kolom pencarian Google Images. Hasil banding dari foto-foto tersebut bisa dianalisa oleh masyarakat; dan 5) Ikut serta dalam grup diskusi anti-hoax. Misalnya dalam platform Facebook, terdapat Forum Anti Fitnah, Hasut dan Hoax (FAFHH), FP \& Group Indonesian Hoax Buster, FP Indonesian Hoaxes serta Grup Sekoci.

\section{Pemberitaan Hoax dalam Perspektif Hukum Indonesia}

Sejumlah peraturan perundang-undangan yang akan dijatuhkan kepada pelaku kejahatan, antara lain KUHP, UU No 11 Tahun 2008 tentang Informasi dan Transaksi Elektronik dan UU No 40 Tahun 2008 tentang Penghapusan Diskriminasi Ras, 
mencerminkan peran penting pemerintah dalam memerangi berita hoax. UU yang ditetapkan oleh Pemerintah tidak berbanding lurus dengan jumlah persidangan yang dilakukan olehpenyebar hoax. Untuk menghindari kekeliruan dan mencegah berkembangnya dampak negatif dari pemberitaan palsu ini, pemerintah telah menempuh prosedur perundangundangan yang diperlukan. Beberapa produk hukum yang dapat digunakan untuk memerangi penyebaran hoaks antara lain Pasal 28 dan 29 Undang-Undang Nomor 11 Tahun 2008 tentang Informasi dan Transaksi Elektronik, Pasal 14 dan 15 Undang-Undang Nomor 1 Tahun 1946, Pasal 311 dan 378 KUHP dan UU No 40 Tahun 2008 tentang Penghapusan Diskriminasi Ras atau Suku. Menyebarkan berita palsu membutuhkan penegakan hukum untuk berhati-hati dan menerapkan alasan hukum yang baik sebelum mengambil tindakan terhadap pelakunya (Mufid \& Hariandja, 2019).

Sebab, tidak semua penyebaran berita bohong merupakan pelanggaran terhadap kepentingan hukum, baik pribadi maupun kolektif. Namun, dalam beberapa kasus, pelaku berita hoax dapat dijerat dengan pasal penipuan atau aib publik. Secara konsep, menyebarkan berita bohong merupakan tindak pidana penipuan. Misalnya, penipuan dalam mengiklankan dan memesan suatu produk (barang) melalui media elektronik dianggap sebagai bentuk penipuan (Pasal 378 KUHP dan Pasal 28 ayat 1 UU).

Perbuatan hoax juga cenderung dikualifikasikan sebagai delik pencemaran nama baik. Hal ini karena berita bohong tidak terkandung dalam kebenaran. Hal ini dalam KUHP tergolong fitnah (Pasal 311 KUHP dan Pasal 27 Ayat 3 UU Informasi dan Transaksi Elektronik). Terkait pemberitaan hoaks yang dapat merugikan kepentingan sosial, hukum seringkali melihat apakah perbuatan terdakwa dapat menimbulkan masalah serius atau tidak, dan dapat menimbulkan rasa kebencian di kalangan masyarakat. UU No. 1 Tahun 1946 tentang Hukum Pidana (14) Ayat 1 berbunyi: "Barangsiapa menyebarkan berita atau pemberitahuan palsu, dengan sengaja membuat keributan di antara orang-orang, dipidana selama sepuluh tahun." Ayat 2 menyebutkan, "Barangsiapa menyiarkan suatu berita atau mengeluarkan suatu pemberitahuan, yang dapat menimbulkan kerusakan di tengah-tengah masyarakat, sedangkan ia dapat menduga bahwa berita atau pemberitahuan itu adalah dusta, dipidana dengan pidana penjara paling lama tiga tahun."

Perbedaan antara kedua ketentuan di atas, khususnya alinea pertama, adalah bahwa penyebaran berita bohong dimaksudkan untuk menimbulkan masalah. Pembuat berita palsu jelas memahami dan berniat menyebarkan berita palsu akan menimbulkan masalah. Sebaliknya, ayat kedua merupakan tindakan penyadaran dengan kemungkinan dia harus mengetahui atau menduga bahwa menyebarkan berita bohong akan menimbulkan masalah. Selain itu, Pasal 28 Ayat 2 Undang-Undang Informasi dan Transaksi Elektronik mengatur penyebaran berita bohong yang dapat menimbulkan kebencian terhadap individu tertentu, yaitu "Setiap orang yang dengan sengaja dan tanpa izin menyebarkan informasi untuk menimbulkan kebencian atau permusuhan terhadap individu dan/atau masyarakat tertentu berdasarkan suku, agama, ras, atau hubungan antargolongan." Artinya, dengan kembali ke peristiwa hukum, sering kali tindakan menyiarkan berita bohong dengan sengaja dengan tujuan menimbulkan kebencian, tidak memuat kebenaran, dapat diklasifikasikan sebagai berita palsu. 


\section{KESIMPULAN}

Berdasarkan penelitian ini, pihak yang menyebarkan menyebarkan berita bohong di Indonesia dipastikan melanggar Pasal 28(1) Nomor 11 Tahun 2008. Oleh karena itu, sangat penting bagi pemerintah untuk memberikan sanksi kepada mereka yang melanggar. Pasal 45a mengatur tentang ancaman terhadap penyebar berita bohong dan pidana penjara paling lama enam tahun, dengan pidana denda paling banyak Rp. 1.000.000.000,- (Satu Miliar Rupiah). Melanggar Pasal 28(1) Undang-Undang Nomor 11 Tahun 2008 yang mengatur tentang Informasi dan Transaksi Elektronik. Metode kritik hadits bisa menjadi acuan bagi masyarakat untuk memverifikasi, apakah berita yang diterima apakah ada penambahan (ziyādah), penyisipan (idrāj), pembalikan (iqlāb) atau pengurangan (nuqshān), serta apakah substansinya sesuai dengan kenyataan atau tidak.

\section{DAFTAR PUSTAKA}

Afandi, I. (2018). Hoax Dalam Sejarah Islam Awal (Kajian Kritis Tentang Qs. An-Nur: 1120). Ar-Risalah: Media Keislaman, Pendidikan dan Hukum Islam, 16(1), 145-161.

Arifin, M. (2018). Pandangan Al-Quran Dalam Merespons Fenomena Hoax: Kajian Tafsir Tematik. Al Itqan: Jurnal Studi Al-Qur'an, 4(1), 91-111.

Azhar, H. (2017). Aspek Pidana dalam Berita Bohong (HOAX) Menurut Fiqh Jinayah. Cendikia: Jurnal Studi Keislaman, 3, 59-70.

Choiroh, L. U. (2017). Pemberitaan Hoax Perspektif Hukum Pidana Islam. Al-Jinayah: Jurnal Hukum Pidana Islam, 3(2), 325-348.

Chumairoh, H. (2020). Ancaman Berita Bohong di Tengah Pandemi Covid-19. Vox Populi, 3(1), 22-30.

Herawati, D. M. (2016). Penyebaran Hoax dan Hate Speech sebagai Representasi Kebebasan Berpendapat. Jurnal Promedia, 2(2).

Hidayat, G. H. A. F. U. R., Eddy, T., \& Sahari, A. (2020). Peran Detasemen Gegana Satuan Brimob Polda Sumatera Utara Dalam Penanggulangan Tindak Pidana Terorisme. Journal of Education, Humaniora and Social Sciences (JEHSS), 3(1), 4451.

Irpan, I. (2020). Melawan Hoax Melalui Sosialisasi Undang-Undang Informasi Dan Transaksi Elektronik. Adi Widya: Jurnal Pengabdian Masyarakat, 4(1a), 32-39.

Junaidi, A., Eddy, T., \& Sahari, A. (2020). Pemberian Sanksi Pidana Bagi Pelaku Penyebaran Hoax Ditinjau Dari Aspek Tindak Pidana Terorisme. Journal of Education, Humaniora and Social Sciences (JEHSS), 3(2), 401-411.

Marwan, M. R., \& Ahyad, A. (2016). Analisis penyebaran berita hoax di Indonesia. Jurusan Ilmu Komunikasi, Fakultas Ilmu Komunikasi Universitas Gunadarma, 5(1), 1-16.

Mufid, F. L., \& Hariandja, T. R. (2019). Efektivitas Pasal 28 Ayat (1) UU ITE tentang Penyebaran Berita Bohong (Hoax). Jurnal Rechtens, 8(2), 179-198.

Mujib, A. (2017). Pesan Al-Quran dalam Menyikapi Berita Hoax: Perspektif Dakwah di Era New Media. Jurnal Komunikasi Islam, 7(1), 42-65.

Novitawati, N. P. D., Parman, L., \& Sabardi, L. (2019). Pertanggungjawaban Pelaku Tindak Pidana Penyebar Berita Bohong (Hoax). Media Bina Ilmiah, 13(11), 1723-1730.

Pakpahan, R. (2017). Analisis Fenomena Hoax Diberbagai Media Sosial Dan Cara Menanggulangi Hoax. Konferensi Nasional Ilmu Sosial dan Teknologi, 1(1).

Pejchal, V. (2018). Hate speech regulation in post-communist countries: migrant crises in the Czech and Slovak Republics. International Journal for Crime, Justice and Social Democracy, 7(2), 58. 
Pranesti, D. A., \& Arifin, R. (2019). Perlindungan Korban dalam Kasus Penyebaran Berita Hoax di Media Sosial di Indonesia. Jurnal Hukum Media Bhakti.

Purnomo, H., \& Yosua, A. (2021). Inkonsistensi Penegakan Hukum Tindak Pidana Hoaks di Indonesia Pasca Reformasi. Jurnal Ius Constituendum, 6(1), 235-251.

Rifauddin, M. A. N. H., \& Halida, A. N. (2018). Waspada cybercrime dan informasi hoax pada media sosial facebook. Khizanah al-Hikmah: Jurnal Ilmu Perpustakaan, Informasi, dan Kearsipan, 6(2), 98-111.

Setiawan, B. (2018). Indonesia Darurat Hoaks?. Informasi, 48(2).

Siddiq, N. A. (2017). Penegakan hukum pidana dalam penanggulangan berita palsu (hoax) menurut Undang-undang No. 11 tahun 2008 yang telah dirubah menjadi Undangundang No. 19 tahun 2016 tentang informasi dan transaksi elektronik. Lex Et Societatis, 5(10).

Toni, T. (2020). Penegakan Hukum Undang-Undang Informasi Dan Transaksi Elektronik Terhadap Hukuman Pengguna Media Sosial Ujaran Kebencian. Informatika, 8(2), 8588. 